\title{
ACE Inhibitory and Antioxidant Activities of Collagen Hydrolysates from the Ribbon Jellyfish (Chrysaora sp.)
}

\author{
Zoha Barzideh ${ }^{1,2 *}$, Aishah Abd Latiff ${ }^{3}$, Chee-Yuen Gan ${ }^{2}$, Md. Zainul Abedin ${ }^{1}$ and \\ Abd Karim Alias ${ }^{1}$ \\ ${ }^{1}$ Food Technology Division, School of Industrial Technology, Universiti Sains Malaysia, \\ 11800 Minden, Penang, Malaysia \\ ${ }^{2}$ Centre for Advanced Analytical Toxicology Services, Universiti Sains Malaysia, \\ 11800 Minden, Penang, Malaysia \\ ${ }^{3}$ Toxicology and Multipurpose Laboratory, Anti Doping Laboratory Qatar, Doha, Qatar
}

Received: March 11, 2014

Accepted: September 17, 2014

\begin{abstract}
Summary
Collagen isolated from the ribbon jellyfish (Chrysaora sp.) was hydrolysed using three different proteases (i.e. trypsin, alcalase and Protamex) to obtain bioactive peptides. Angiotensin-I-converting enzyme (ACE) inhibitory activity and antioxidant activities (i.e. ferric reducing antioxidant power (FRAP) and 2,2-diphenyl-1-picrylhydrazyl (DPPH) radical scavenging activity) of the peptides were measured and compared, and the effect of the duration of hydrolysis on the bioactivity (ACE inhibitory and antioxidant activities) of peptides was also evaluated. FRAP activity was the highest in Protamex-induced (25-27 $\mathrm{mM}$ ) and trypsin-induced hydrolysates $(24-26 \mathrm{mM})$ at 7 and $9 \mathrm{~h}$, respectively. Conversely, hydrolysates produced by trypsin for 1 and $3 \mathrm{~h}$ showed the highest DPPH radical scavenging activities (94 and $92 \%$, respectively). Trypsin-induced hydrolysates (at $3 \mathrm{~h}$ ) also showed the highest ACE inhibitory activity (89\%). The peptide sequences with the highest activities were identified using tandem mass spectrometry, and the results show that the hydrolysates had a high content of hydrophobic amino acids as well as unique amino acid sequences, which likely contribute to their biological activities.
\end{abstract}

Key words: collagen, protein hydrolysates, ACE inhibition, antihypertensive activity, antioxidant activity, DPPH, FRAP, Chrysaora sp., jellyfish

\section{Introduction}

Hypertension is one of the most common lifestyle-related diseases and has become one of the most significant health problems in recent years (1). Angiotensin-I-converting enzyme (ACE; EC 3.4.15.1) is a circulating enzyme that plays an important physiological role in regulating blood pressure by converting angiotensin I (inactive form) to angiotensin II, which is a potential vasoconstrictor, or by inactivating bradykinin, which is a vasodilator (2-5). Therefore, inhibition of ACE can be used to suppress blood pressure elevation and to treat myocardial infarction and other cardio-related diseases $(2,4)$.
A negative result of angiotensin II production is the formation of intercellular reactive radicals. Free radicals are the product of normal aerobic reactions in organisms and they play anti-infection roles. However, if their levels exceed normal levels, they can cause diseases such as cancer, arthritis, atherosclerosis, and diabetes (2). Increased concentrations of free radicals in the body can also occur via the consumption of oxidant-containing foods (6). Thus, neutralizing radicals both in foods and in the body can be helpful in the prevention and treatment of diseases.

In recent years, there has been growing interest in finding safe alternatives to artificial antioxidants and syn- 
thetic antihypertensive (ACE inhibitor) medicines because of their health risks and side effects. Biologically active peptides have antioxidant and/or antihypertensive activities and also possess nutritive value; thus they may prove to be useful in the pharmaceutical and food industries (7). Bioactive peptides have been isolated from different proteins, including soy (8), whey (9), and casein (10), and from various marine sources such as fish-derived proteins, e.g. sardine, tuna, cod, bonito (3), and waste from fish processing facilities $(2,11)$. More and more investigations are being conducted to identify potential sources of bioactive peptides $(4,6,7)$. Although collagen peptides are assumed to exhibit high antiradical and antihypertensive activities due to their high content of hydrophobic amino acids $(5,6,12)$, to date few studies have focused on collagen or gelatin hydrolysates as a source of these peptides.

Proteolytic hydrolysis of proteins is the most effective method for the production of bioactive peptides because the process releases bioactive fragments that are inactive within the protein chain (13). Moreover, by controlling the enzymatic hydrolysis process, polypeptides of certain sizes can be obtained, and they can be modified to improve their functional properties (6). The characteristics and bioactivity of protein hydrolysates depend on many factors, including type of protease, enzyme-to-substrate ratio, concentration of the substrate, incubation time, temperature, and $\mathrm{pH}(7)$. The effects of different enzymes (e.g. trypsin, alcalase, Protamex, pepsin, and others) and variations of other parameters have been evaluated in studies focused on the preparation and optimization of bioactive peptides. However, to identify the optimal conditions for isolating bioactive peptides from any individual source, the effects of different proteases and other conditions must be studied individually.

Jellyfish, which are often abundant in coastal waters, have been used as a food source in Asia, particularly China, for more than a thousand years. They have also been used for a traditional treatment of diseases such as hypertension, arthritis, gastric ulcer, and many others. The use of enzymatic hydrolysates of jellyfish collagen as antioxidant and/or antihypertensive reagents could add value to this underutilized resource, and the hydrosylation process could provide a multifunctional ingredient with potential applications in the pharmaceutical, nutraceutical, and food and dietary supplement industries.

The ribbon jellyfish (Chrysaora sp., class Scyphozoa, order Semaeostomeae) has recently been found in the coastal area around Penang Island, Malaysia, in huge blooms. Its bell is about $8-12 \mathrm{~cm}$ in diameter, and its flat and ribbon-like oral arms are $20-50 \mathrm{~cm}$ long (14). In this study we extracted collagen and subsequently produced collagen hydrolysates from Chrysaora sp. using three different enzymes (trypsin, alcalase and Protamex). The ACE inhibitory and antioxidant activities of the different hydrolysates were then measured and compared. Finally, potential bioactive peptide sequences present in highly bioactive (ACE inhibitor or antioxidant) samples were identified.

\section{Materials and Methods}

\section{Materials}

Ribbon jellyfish (Chrysaora sp.) were caught along the north coast of Penang Island, Malaysia in March 2011. The umbrella was dissected, washed with deionized water, and stored at $-80^{\circ} \mathrm{C}$ until use.

\section{Chemicals and reagents}

Pepsin (EC 3.4.23.1, $\geq 400 \mathrm{U}$ per mg of protein) and tryp$\sin$ (EC 3.4.21.4) were purchased from Sigma-Aldrich Inc. (St. Louis, MO, USA). Alcalase (EC 3.4.21.62) and Protamex ${ }^{\mathrm{TM}}$ (Bacillus protease complex, EC 3.4.21.62 and 3.4.24.28) were supplied by Novozymes A/S (Bagsværd, Denmark). SDS-PAGE reagents and molecular mass markers were purchased from Bio-Rad Laboratories (Hercules, CA, USA). All chemicals and reagents were of analytical grade.

\section{Isolation of collagen}

Collagen was extracted according to the method of Nagai et al. (15) with slight modification as described by Barzideh et al. (16). All procedures were performed at 4 ${ }^{\circ} \mathrm{C}$. Jellyfish umbrellas were thawed at $4{ }^{\circ} \mathrm{C}$ for $4-5 \mathrm{~h}$, cut into small pieces $(0.5 \mathrm{~cm} \times 0.5 \mathrm{~cm})$, and washed with distilled water. To remove non-collagenous substances, each sample was treated with $0.1 \mathrm{M} \mathrm{NaOH}$ at a sample/solution ratio of 1:10 (mass per volume) with gentle stirring for 2 days; the solution was changed once a day. After centrifugation at $10000 \times g$ for $30 \mathrm{~min}$, the remaining insoluble matter was washed with distilled water until neutral $\mathrm{pH}$ was achieved. It was then suspended in $0.5 \mathrm{M}$ acetic acid (10 $\mathrm{mL}$ of acetic acid for each gram of collagenous material) containing $10 \%$ (by mass) pepsin with gentle stirring for 3 days (digestion process). The final viscous liquid was centrifuged at $20000 \times g$ and $4{ }^{\circ} \mathrm{C}$ for $1 \mathrm{~h}$. Digestion of the remaining pellet was carried out once more, and the supernatants were combined. The supernatant was dialysed against 10 volumes of $0.02 \mathrm{M} \mathrm{Na}_{2} \mathrm{HPO}_{4}(\mathrm{pH}=8.8)$ for 3 days to inactivate the enzyme. The dialysed sample was centrifuged at $20000 \times g$ and $4{ }^{\circ} \mathrm{C}$ for $1 \mathrm{~h}$. The resulting precipitate was dissolved in $0.5 \mathrm{M}$ acetic acid and salted out by adding $\mathrm{NaCl}$ to a final concentration of $1 \mathrm{M}$, followed by centrifugation at $20000 \times g$ and $4{ }^{\circ} \mathrm{C}$ for $1 \mathrm{~h}$. The resulting precipitate was dissolved in $0.5 \mathrm{M}$ acetic acid and dialysed against distilled water for 2 days. The sample, called jellyfish pepsin-solubilized collagen (JPSC), was lyophilised and stored at $-80^{\circ} \mathrm{C}$ until further analysis.

\section{Preparation of collagen hydrolysates}

Samples $(100 \mathrm{mg})$ of the isolated pepsin-solubilised collagen (JPSC) were suspended in $100 \mathrm{~mL}$ of distilled water and digested using one of three different enzymes at an enzyme-to-substrate ratio of 1:50 (by mass). Digestion was carried out for $9 \mathrm{~h}$ at $50{ }^{\circ} \mathrm{C}$, and optimum $\mathrm{pH}$ values for each enzyme (as suggested by the manufacturer and previous research) were as follows: $\mathrm{pH}=8$ for alcalase and trypsin, and $\mathrm{pH}=7$ for Protamex $(17,18)$. To evaluate the effect of the duration of exposure to the enzyme on the degree of hydrolysis and bioactivity (ACE inhibitory and antioxidant activities) of the peptides, samples were taken at 0 (non-hydrolysed collagen), 1, 3, 5, 7, and $9 \mathrm{~h}$. After $9 \mathrm{~h}$, the hydrolytic reaction was terminated by heating the samples at $95^{\circ} \mathrm{C}$ for $10 \mathrm{~min}$. The samples were then cooled to room temperature and centrifuged at $1077 \times g(3000 \mathrm{rpm})$ for $30 \mathrm{~min}$. The resulting supernatants were lyophilised as jellyfish collagen hydrolysates (JCHs) and stored at $-80^{\circ} \mathrm{C}$ for further analysis. 


\section{Degree of hydrolysis of collagen hydrolysates}

The method by Hoyle and Merritt (19) was used to determine the degree of hydrolysis (DH) of all the isolated JCHs. Trichloroacetic acid (TCA, $20 \%$ ) was mixed with an equal volume of the hydrolysate solution. TCA-soluble materials $(10 \%)$ were collected after centrifugation at $7000 \times g$ for $20 \mathrm{~min}$ at $10^{\circ} \mathrm{C}$. The nitrogen content was measured according to the Kjeldahl method (20). The following equation was used to compute the $\mathrm{DH}$ :

$$
\mathrm{DH}=\left(\frac{\text { nitrogen soluble in } 10 \% \mathrm{TCA}}{\text { total nitrogen in the sample }}\right) \cdot 100
$$

\section{Amino acid composition of collagen hydrolysates}

To determine the amino acid composition of the extracted collagen hydrolysates, $0.1 \mathrm{~g}$ of the freeze-dried $\mathrm{JCH}$ samples prepared using all of the enzymes were hydrolysed with $6 \mathrm{M} \mathrm{HCl}(5 \mathrm{~mL})$ at $110{ }^{\circ} \mathrm{C}$ for $24 \mathrm{~h}$. Subsequently, $400 \mu \mathrm{L}$ of $50 \mu \mathrm{mol} / \mathrm{mL}$ of $\mathrm{L}-\alpha$-amino- $n$-butyric acid (AABA) were added (as the internal standard) to the resulting hydrolysates, and distilled deionized water was added to reach a volume of $100 \mathrm{~mL}$. Samples were then filtered through Whatman no. 1 filter paper, and then through 0.22- $\mu \mathrm{m}$ Millipore filter (21). The amino acids of the JPSC hydrolysate were derivatised by incubating 10 $\mu \mathrm{L}$ of the hydrolysed samples with $20 \mu \mathrm{L}$ of AccQ.Fluor ${ }^{\mathrm{TM}}$ reagent (also known as AQC, and 6-aminoquinolyl- $N$-hydroxysuccinimidyl carbamate) (Waters Corporation, Milford, MA, USA) for $1 \mathrm{~min}$ at room temperature. Samples were then placed on the $150-\mu \mathrm{L}$ glass with polyspring insert (Thermo Scientific, San Jose, CA, USA), which was equipped with the screw-capped vial, and the vial was heated for $10 \mathrm{~min}$ at $55^{\circ} \mathrm{C}$ before analysis.

The derivatised samples were analysed using a HPLC (Waters Corporation). For each sample, a $10-\mu \mathrm{L}$ aliquot was injected into the column, and the solution was eluted at a flow rate of $1 \mathrm{~mL} / \mathrm{min}$. Determination of amino acids was carried out according to the AccQ.Tag ${ }^{\mathrm{TM}}$ method using the Waters HPLC system equipped with a Waters 1525 binary pump, Waters 717 plus autosampler, Waters 2475 Multi $\lambda$ fluorescence detector, and Waters AccQ. Tag ${ }^{\mathrm{TM}}$ amino acid analysis column $(3.9 \mathrm{~mm} \times 150 \mathrm{~mm}$; packing material: silica-based bonded with $\mathrm{C}_{18}$ ). The column was fixed at $37^{\circ} \mathrm{C}$ with fluorescence detection at $250 \mathrm{~nm}$ for excitation and at $395 \mathrm{~nm}$ for emission. AccQ·Tag ${ }^{\mathrm{TM}}$ eluent $\mathrm{A}$ and acetonitrile/water (60:40) were used as eluents, and calibration of the HPLC system was performed using the amino acid standard H (Pierce, Rockford, IL, USA) as the reference. Methionine and cysteine were analysed separately using the performic acid procedure described by Moore (22). Breeze Workstation v. 3.20 (Waters Corporation) was used for data analysis. The area under the peak of each amino acid in the chromatogram was calculated and compared with that of the standard. The analysis was carried out in triplicate, and the results are reported as per 1000 amino acid residues.

\section{Antioxidant activity of collagen hydrolysates}

Ferric reducing/antioxidant power assay

The ferric ion reducing antioxidant power (FRAP) assay was performed according to the method of Benzie and Strain (23). It measures the capacity of a sample to reduce
$\mathrm{Fe}^{3+}$-tripyridyltriazine (TPTZ) to $\mathrm{Fe}^{2+}$-TPTZ (blue colour). The FRAP reagent was prepared by combining $10 \mathrm{mM}$ TPTZ with $40 \mathrm{mM} \mathrm{HCl}, 20 \mathrm{mM} \mathrm{FeCl}_{3} \cdot 6 \mathrm{H}_{2} \mathrm{O}$ and $0.3 \mathrm{M}$ acetate buffer $(\mathrm{pH}=3.6)$, at a ratio of 1:1:10.

In this assay, a 2.7- $\mu \mathrm{L}$ sample of JCHs (an aliquot containing $1 \mathrm{mg}$ of $\mathrm{JCH}$ in $1 \mathrm{~mL}$ of distilled water) was mixed with $200 \mu \mathrm{L}$ of prewarmed FRAP reagent at $37^{\circ} \mathrm{C}$ and incubated at $37^{\circ} \mathrm{C}$ for $1 \mathrm{~h}$. Absorbance was then measured at $593 \mathrm{~nm}$ using a spectrophotometer (Spectramax M5, Molecular Devices, Sunnyvale, CA, USA). The antioxidant potential of the samples was determined according to a standard curve generated using a $0-2 \mathrm{mM}$ solution of $\mathrm{FeSO}_{4} \cdot 7 \mathrm{H}_{2} \mathrm{O}$. FRAP values were expressed as $\mathrm{mM}$ of $\mathrm{FeSO}_{4} \cdot 7 \mathrm{H}_{2} \mathrm{O}$ equivalent per $\mathrm{mg}$ of freeze-dried sample.

\section{DPPH free radical scavenging assay}

The antioxidant capacity of JPSC and JCHs was determined using the DPPH radical scavenging assay according to the method of Lee et al. (24). An aliquot of $6.66 \mu \mathrm{L}$ of sample $(1 \mathrm{mg} / \mathrm{mL})$ was mixed with $200 \mu \mathrm{L}$ of DPPH reagent $(0.1 \mathrm{mM}$ in ethanol). The mixture was then mixed and incubated at $30^{\circ} \mathrm{C}$ for $30 \mathrm{~min}$ in the dark. The absorbance of the sample was measured at $517 \mathrm{~nm}$ using a spectrophotometer (Spectramax M5). The control consisted of methanol instead of the sample. Gallic acid at concentrations ranging from 0 to $60 \mu \mathrm{g} / \mathrm{mL}$ was used as the standard. The results are expressed as percentage of inhibition of DPPH radicals using the following equation:

$$
\mathrm{DPPH}=\left(\left(A_{\text {control }}-A_{\text {sample }}\right) / A_{\text {control }}\right) \cdot 100
$$

where $A_{\text {sample }}$ is the absorbance of the samples at different times and $A_{\text {control }}$ is the absorbance of DPPH solution without the sample.

\section{Evaluation of ACE inhibitory activity of collagen hydrolysates}

The ACE inhibitory activity was measured according to the method of Cushman and Cheung (25) with modifications. For this analysis, a sample $(50 \mu \mathrm{L}$ at a concentration of $1 \mathrm{mg} / \mathrm{mL}$ ) was mixed with $50 \mu \mathrm{L}$ of ACE solution $(50 \mathrm{mU} / \mathrm{mL}$ in sodium borate buffer, $\mathrm{pH}=8.3$ ) and incubated at $37^{\circ} \mathrm{C}$ for $10 \mathrm{~min}$. Next, $150 \mu \mathrm{L}$ of hippuryl-histidyl-leucine $(4.15 \mathrm{mM}$ in borate buffer containing $0.3 \mathrm{M}$ $\mathrm{NaCl}, \mathrm{pH}=8.3$ ) were added to the standard reaction mixture and incubated at $37^{\circ} \mathrm{C}$ for $30 \mathrm{~min}$. The reaction was stopped by adding $500 \mu \mathrm{L}$ of $1 \mathrm{M} \mathrm{HCl}$. To extract the resulting hippuric acid, $1.5 \mathrm{~mL}$ of ethyl acetate were added and the mixture was vortexed for $1 \mathrm{~min}$. After resting for 5 $\min , 800 \mu \mathrm{L}$ of the ethyl acetate layer were removed and vacuum dried in a vacuum concentrator (Concentrator 5301, Eppendorf, Hamburg, Germany) at $45^{\circ} \mathrm{C}$ for $30 \mathrm{~min}$. The dried sample was dissolved in $1 \mathrm{~mL}$ of distilled water, and the absorbance was measured at $228 \mathrm{~nm}$ using a spectrophotometer (Spectramax M5). Positive and negative controls consisted of $50 \mu \mathrm{L}$ of $1 \mathrm{M} \mathrm{HCl}$ and $50 \mu \mathrm{L}$ of distilled water, respectively, instead of the sample. The ACE inhibitory activity was calculated using the equation:

$$
\text { ACE inhibition }=\left(\left(A_{\text {negative }}-A_{\text {sample }}\right) / A_{\text {negative }}\right) \cdot 100
$$

where $A_{\text {negative }}$ is the absorbance of the negative control, and $A_{\text {sample }}$ is the absorbance of the sample at different times. The absorbance of the positive control was used as the reading correction. 


\section{Identification of bioactive peptides extracted from collagen hydrolysates}

To identify the bioactive peptides in the JCHs, the peptides with the highest DPPH radical scavenging activity, FRAP reducing activity, and ACE inhibitory activity were subjected to peptide sequencing using mass spectrometry. A $200-\mu \mathrm{L}$ aliquot containing $2 \mathrm{mg} / \mathrm{mL}$ of JCH in distilled water was filtered through a syringe filter $(2 \mu \mathrm{m}$, Amicon, Merck Millipore, Carrigtwohill, County Cork, Ireland). Mass spectroscopy of the sample was then conducted using a Thermo LTQ/Orbitrap Velos coupled with an EASY-nLC II system (Thermo Scientific).

Chromatographic separation of peptides was performed using an EASY-Column C18-A2 (100 $\mathrm{mm} \times 0.075$ $\mathrm{mm}$ i.d., particle size $3 \mu \mathrm{m}$ ) coupled with a precolumn (EASY-Column, $200 \mathrm{~mm} \times 0.1 \mathrm{~mm}$ i.d., particle size $5 \mu \mathrm{m}$ ) (both from Thermo Scientific) at a flow rate of $0.3 \mu \mathrm{L} / \mathrm{min}$; the injection volume of the sample was $10 \mu \mathrm{L}$. The precolumn was equilibrated for $15 \mu \mathrm{L}$ at a flow rate of $3 \mu \mathrm{L} / \mathrm{min}$, while the analytical column was equilibrated for $4 \mu \mathrm{L}$ at a flow rate of $0.3 \mu \mathrm{L} / \mathrm{min}$. Running buffers were used as follows: deionized distilled water with $0.1 \%$ formic acid (A), and acetonitrile with $0.1 \%$ formic acid (B). The pump gradient elution of nano-LC was as follows: $0-70 \mathrm{~min}, 5-45 \%$ B; 70-85 min, 45-100 \% B; and 85-100 min, $100 \%$ B.

The eluent was sprayed into the mass spectrometer at $2.3 \mathrm{kV}$ (source voltage), and a capillary temperature of 200 ${ }^{\circ} \mathrm{C}$ was used. Peptides were detected by full scan mass analysis from $\mathrm{m} / \mathrm{z}=200-2000$ at resolving power of 60000 (at $m / z=400$, full width at half maximum (FWHM); 1-s acquisition) with data-dependent MS/MS analyses (ion trap mass spectrometry, ITMS) triggered by the eight most abundant ions from the parent mass list of predicted peptides with the rejection of single or unassigned charge state. The ITMS analysis was performed using the same resolving power $(60000)$, and collision-induced dissociation (CID) was conducted with isolation width of $2 \mathrm{Da}$, normalized collision energy of 35 , activation $q$ of 0.25 , activation time of $50 \mathrm{~ms}$, and charge state of 2 or higher.

Data acquisition was performed using Xcalibur v. 2.1 (Thermo Scientific) with a mass tolerance threshold of 5 ppm. Data analysis was performed using PEAKS studio v. 6.0 (Bioinformatic Solutions Inc., Waterloo, Canada) and Peptide Ranker (ShieldsLab, Dublin, Ireland).

\section{Statistical analysis}

All experiments were performed at least in triplicate, and data are presented as mean \pm standard deviation. Analysis of variance (ANOVA) was performed and comparisons of the mean values were conducted using Duncan's multiple range tests. Differences were considered significant at the probability value of $\mathrm{p}<0.05$. Analysis was performed using SPSS v. 20 for Mac OS (IBM, Armonk, NY, USA).

\section{Results and Discussion}

\section{Degree of hydrolysis}

Degree of hydrolysis (DH) is an important parameter when monitoring the hydrolysis process and comparing different protein hydrolysates in terms of peptide length, functional and sensory properties, and nutritional value $(6,11)$. DH is directly correlated with the solubility of the protein hydrolysates, which is increased through digestion of the parent protein (11).

Fig. 1 shows the $\mathrm{DH}$ of the JCHs digested using the three enzymes over the course of the incubation period. The hydrolysis of all enzymes was fast during the initial stage of the process $(3-5 \mathrm{~h})$, but then the rate of hydrolysis gradually decreased until it reached a stationary phase, during which no apparent hydrolysis took place. This result, which shows that most peptides were cleaved within the first 3-5 h of hydrolysis, is in agreement with the classic protease-induced hydrolysis reported for other proteins (26). However, there is a difference between the patterns of hydrolysis using Protamex and the other two enzymes. Increase of DH was biphasic when using trypsin and alcalase, while it was monophasic when using Protamex. It has been suggested that the activity of alcalase and trypsin starts with hydrolysing some reachable sites (up to $3 \mathrm{~h}$ of hydrolysis, phase 1). After cleavage of the first susceptible bonds and deformation of the polypeptide chain, new susceptible bonds become exposed to the enzyme. Therefore, cleavage goes fast again for another phase (up to $5 \mathrm{~h}$, phase 2) before reaching a stationary phase (biphasic hydrolysis). However, with Protamex, which is a mixture of two enzymes and is specialized in cleaving the peptide bonds at certain sites, cleavage of all target bonds occurs simultaneously. Therefore, the hydrolysis trend using Protamex is monophasic.

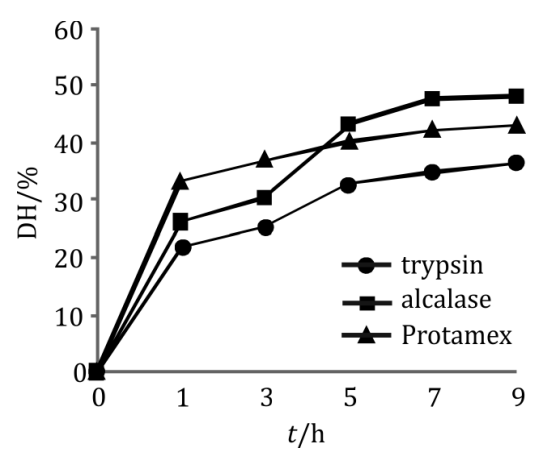

Fig. 1. Enzymatic hydrolysis of jellyfish collagen using trypsin, alcalase, and Protamex. DH=degree of hydrolysis

During the first $3 \mathrm{~h}$ of hydrolysis, exposure of JPSC to Protamex resulted in the highest $\mathrm{DH}(37 \%)$; values for alcalase and trypsin were 30 and $25 \%$, respectively. However, after $9 \mathrm{~h}$ of hydrolysis, the highest DH was found in the JCH produced by alcalase ( $48 \%$ ), followed by Protamex $(43 \%)$ and trypsin $(36 \%)$. This result is in agreement with other studies that reported alcalase to be more efficient than trypsin (26). In our experiment, the parent protein was identical in all three treatments, and hydrolysis conditions were optimized for each enzyme. Thus, the difference in DH among treatments might be due to the ability of the different enzymes to cleave certain hydrolysable bonds (6).

DH is an important factor affecting the bioactivity of protein hydrolysates because it influences the size of peptides and the exposure of certain amino acids or functional 
groups at the peptide terminals (26). Therefore, to evaluate the effect of DH on the bioactivity (ACE inhibitory and antioxidant activities) of hydrolysates, all assays were carried out on JCHs digested using the three different enzymes at every hour of hydrolysis.

\section{Amino acid content}

Table 1 shows the amino acid composition of the JCHs expressed per 1000 amino acid residues. The amino acid composition of all JCH samples hydrolysed by three enzymes was similar, and also similar to that of jellyfish collagen (16) and to the typical profile of collagen, with Gly as the most abundant amino acid (32\%) (26) and with Hyp present.

Table 1. Amino acid composition of jellyfish collagen hydrolysates $(\mathrm{JCHs})$ per 1000 residues

\begin{tabular}{cr}
\hline Amino acid & JCH \\
\hline Hyp & 39 \\
Asp & 69 \\
Ser & 60 \\
Glu & 82 \\
Gly & 319 \\
His & ND \\
Arg & 42 \\
Thr & 44 \\
Ala & 91 \\
Pro & 73 \\
Cys & ND \\
Tyr & 14 \\
Val & 27 \\
Met & 20 \\
Lys & 23 \\
Ile & 31 \\
Leu & 43 \\
Phe & 23 \\
Total & 1000 \\
Total hydrophobic & 641 \\
\hline
\end{tabular}

*Hydrophobic amino acids: Leu, Ile, Phe, Ala, Val, Tyr, Met, Gly, Pro. $\mathrm{ND}=$ not detected

The amino acid profile revealed that amino acids mainly consisted of hydrophobic residues. Wan Mohtar et al. (27) reported that the presence of a considerable quantity of hydrophobic amino acids in peptide sequences contributes to ACE inhibitory activity and antioxidant activity in several bioactive peptides. Among the hydrophobic amino acids, Gly was dominant with 319 residues. Ala and Pro were the next most abundant hydrophobic amino acids, with 91 and 73 residues, respectively, followed by Leu, Ile, Val, Phe, Met, and Tyr. The JCHs also contained a high amount of the non-hydrophobic amino acids Asp (69 residues) and Glu (82 residues), which have been reported to exhibit high antioxidant activity due to the donation of electrons to free radicals $(13,28)$.
Pro plays an important role in ACE inhibitory and antioxidant activities $(27,29)$. The presence of Tyr, Trp, Met, Lys $(2,13,28)$, Pro, Leu, and Asp has also been reported to contribute to the antioxidant activity (29), and a high content of Gly, Pro, Ala, Glu, and Asp has been found in many other ACE inhibitory peptides (13). Therefore, the amino acid composition of the JCHs indicates that they have antioxidant and/or ACE inhibitory properties.

\section{Antioxidant activity}

Antioxidant activity of proteins and peptides is not attributed to a single mechanism because proteins contain various amino acids with different antioxidant properties. Some antioxidant components are more effective in metal chelating, whereas some others are radical scavengers or lipid peroxidation inhibitors $(26,30)$. Thus, different antioxidant assays are required to evaluate the antioxidant capacity of protein hydrolysates, and none of them can individually be referred to as a standard method. In this study, FRAP and DPPH radical scavenging assays were applied to investigate the antioxidant activity of the JCHs.

\section{Results of FRAP assay}

The ability of the sample to reduce the ferric ion is an indicator of potential antioxidant activity. In this process, the free radical is neutralized by receiving an electron donated by the reducing agent (i.e. the sample) and subsequently by acquiring a hydrogen from its environment solution (6). In this assay, the result of the reduction of ferric $\left(\mathrm{Fe}^{3+}\right)$ to ferrous $\left(\mathrm{Fe}^{+2}\right)$ ion in the FRAP reagent is the formation of $\mathrm{Fe}^{2+}-\mathrm{TPTZ}$, which is a blue-coloured complex with the highest absorbance at $593 \mathrm{~nm}$ (30).

Fig. 2 shows the ferric reducing capacity of non-hydrolysed JPSC and the JCHs. The JCH samples had higher values than the non-hydrolysed collagen, probably due to the release of protons and electrons (hydrogen ions) during hydrolysis (31). The ability of all three JCHs to scavenge ferric ion increased as incubation time increased, with the highest activity at 7 and $9 \mathrm{~h}$, with no significant difference for each individual JCH ( $p>0.05)$. Among the three enzymes tested, digestion with Protamex and trypsin resulted in the highest FRAP activities, which might be due to the release of peptides with certain sequences as well as exposure of some amino acid residues (Tyr, Lys, and Met) and side chains that exhibit higher antioxidant activity $(6,13)$.

The correlation between the $\mathrm{DH}$ and reducing capacity is not always clear. For example, the alcalase-induced hydrolysate with the highest $\mathrm{DH}$ had the lowest reducing power, and the reducing power of the Protamex-induced hydrolysate and the trypsin-induced hydrolysate did not differ significantly even though the former had a higher $\mathrm{DH}$ than the latter. This might be due to the position of specific amino acids within the peptide sequences that confer antioxidant activity to the purified peptide (29).

\section{Results of DPPH free radical scavenging activity assay}

$\mathrm{DPPH}$ is an organic nitrogen radical. The percentage of DPPH radical inhibition by the sample within a certain period of time is an indicator of the antioxidant capacity of the sample (13). JPSC and JCHs obtained using different enzymes for various periods of incubation were evaluated 
a)

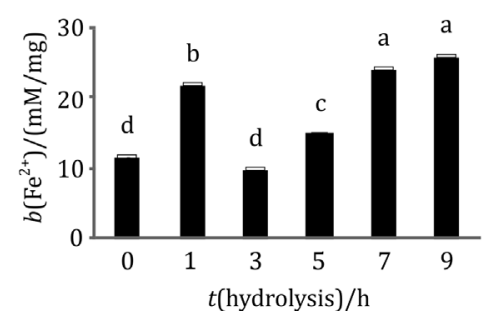

b)

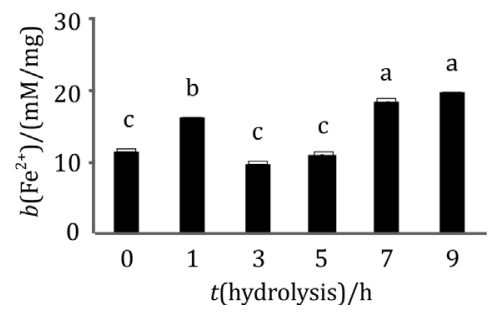

c)

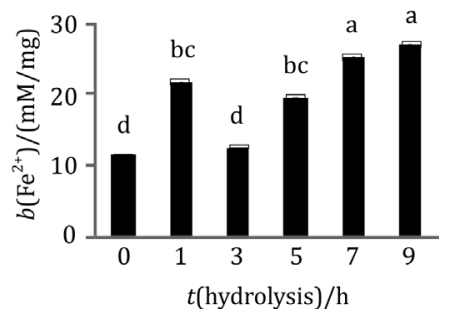

Fig. 2. Results of the FRAP assay for hydrolysates produced using: a) trypsin, b) alcalase and c) Protamex. Different letters (a, b, c and $d$ ) in each graph (within the same hydrolysate) indicate significant differences $(p<0.05)$. Data are the mean values \pm standard deviation from at least three repetitions

for their radical scavenging activity. Although DPPH radical scavenging activity was observed in both non-hydrolysed collagen and collagen hydrolysates, the latter showed higher values (Fig. 3). This result shows that enzymatic hydrolysis improved the antioxidant activity via the release of low molecular mass peptides and by increasing the exposure of hydrogen-donating amino acids $(13,30)$.

For all of the JHCs, the highest value of DPPH scavenging activity was observed within the first 1 to $3 \mathrm{~h}$ of hydrolysis, with no significant differences among enzyme treatments $(\mathrm{p}<0.05)$. However, as the duration of hydrolysis increased, DPPH scavenging activity decreased. This result emphasizes the premise that the size of the peptide plays an important role in the bioactivity of the peptide. Excess hydrolysis might have a reverse effect by producing very short peptides or free amino acids that do not exhibit radical scavenging activity (13).

The DPPH scavenging activity of the trypsin-induced $\mathrm{JCH}$ was more than two times higher than that of the non- -hydrolysed collagen, and the values of Protamex and alcalase were following the trypsin-induced one. Several factors, including amino acid composition, $\mathrm{DH}$, peptide size, peptide sequence, and type of the applied enzyme, can influence the antioxidant capacity of the collagen hydrolysate. For the JCHs in this study, the parent protein used in all treatments was the same, so the observed differences cannot be due to amino acid composition; however, they might be due to various amino acid sequences within the peptides (particularly at $\mathrm{N}$ - and C-terminals) or various peptide lengths (2).

\section{ACE inhibitory activity of collagen hydrolysates}

The JCHs were subjected to the ACE inhibitory activity assay to identify the hydrolysates with the highest activities. All sample types, including the non-hydrolysed collagen, showed ACE inhibition activity to some extent, but treatment with the three enzymes resulted in significantly increased ACE inhibitory activity (Fig. 4). Therefore, enzymatic hydrolysis seems essential to cleave the a)

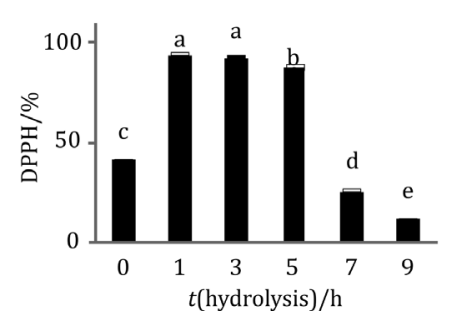

b)

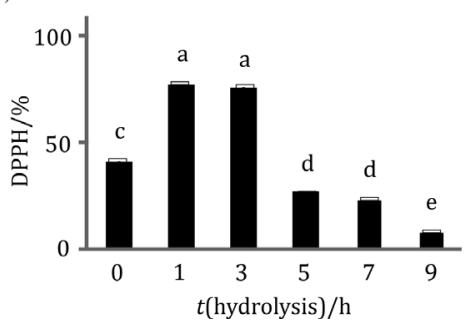

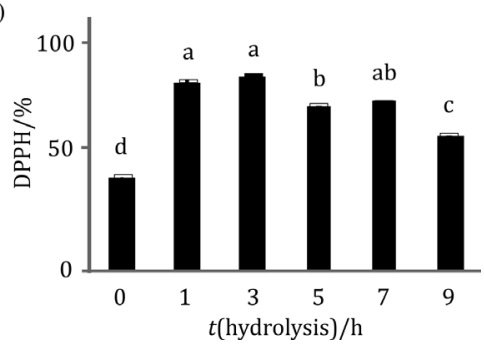

Fig. 3. Results of the DPPH scavenging assay for hydrolysates produced using: a) trypsin, b) alcalase and c) Protamex. Different letters $(a, b, c, d$ and e) in each graph (within the same hydrolysate) indicate significant differences $(p<0.05)$. Data are the mean values \pm standard deviation from at least three repetitions

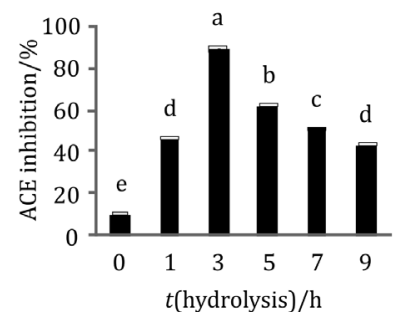

b)

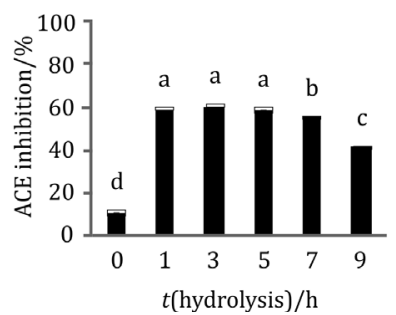

c)

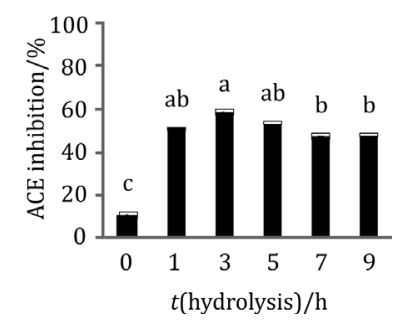

Fig. 4. Results of the ACE inhibitory activity assay for hydrolysates produced using: a) trypsin, b) alcalase and c) Protamex. Different letters $(a, b, c, d$ and e) in each graph (within the same hydrolysate) indicate significant differences $(p<0.05)$. Data are the mean values \pm standard deviation from at least three repetitions 
collagen and release ACE inhibitory peptides. The observed bioactivity (ACE inhibitory and antioxidant activities) of non-hydrolysed collagen might be due to partial hydrolysis of collagen during the process of suspending the collagen in water.

A direct correlation between the incubation time and ACE inhibition activity was observed only up to $3 \mathrm{~h}$ in case of all enzymes; after $3 \mathrm{~h}$ the activity decreased. This result again emphasizes the important role of peptide size in defining its bioactivity. However, different enzymes with almost the same DH did not show the same ACE inhibitory potency. For example, the hydrolysates produced by exposure to alcalase for $1 \mathrm{~h}$ and trypsin for $3 \mathrm{~h}$ had similar DH values (26 and $25 \%$, respectively), but different ACE inhibitory values (59 and $89 \%$, respectively). The hydrolysates generated by incubation with trypsin for $5 \mathrm{~h}$ and Protamex for $1 \mathrm{~h}$ both had $33 \% \mathrm{DH}$, but their ACE inhibitory values were 34 and $51 \%$, respectively. On the other hand, some of the peptides with different DH (hydrolysed by different enzymes) showed similar ACE inhibitory activities. For example, the hydrolysates produced by exposure to alcalase for $1 \mathrm{~h}(59 \% \mathrm{DH})$ and Protamex for $3 \mathrm{~h}(26 \% \mathrm{DH})$ had similar ACE inhibitory values. These observations suggest that instead of the size of the peptide or the $\mathrm{DH}$, the amino acid sequence of the collagen hydrolysates might be important element in determining the bioactivity of a peptide (3).

The trypsin-induced hydrolysates showed the highest ACE inhibitory activity, followed by alcalase and Protamex. In studies of marine protein sources and corn gluten $(7,32,33)$, Protamex was reported to be more effective than alcalase, whereas Alemán et al. (26) found that they were equally effective. In some studies, trypsin was more effective in producing ACE inhibitors than alcalase (3), but in other cases alcalase was more effective $(18,34)$. These different actions of the same enzyme on different substrates or different enzymes on the same substrate (as in our study) indicate that along with $\mathrm{DH}$ and other parameters, the protein sequence of the substrate or the effectiveness of a protease on a certain substrate (i.e. substrate specificity) is a very important factor (7). Therefore, it is crucial to select an appropriate protease to produce specific bioactive peptide sequences, and this choice depends on the raw material proteins and the expected bioactivity.

\section{Potential bioactive peptides from collagen hydrolysates}

After identifying the samples with the highest bioactivity (FRAP, DPPH and ACE inhibition), the relevant hydrolysates were analysed to determine their amino acid sequence. Using mass spectroscopy and PEAKS studio software v. 6.0, peptide sequences present in the samples were identified. Next, by applying the results to PeptideRanker software (screening of peptides with the certainty of more than $50 \%$ ) (35), peptide sequences that may have high antioxidant and ACE inhibitory were identified (Table 2).

All of these peptides contain 7 to 16 amino acid residues, which is the reported range for bioactive peptides (2-20 residues) (36). The molecular mass of these peptides ranged from 677 to $1351 \mathrm{Da}$. Many of the ACE inhibitory peptides have been reported to be shorter than $1500 \mathrm{Da}$ (18). Low molecular mass peptides are able to pass through the intestine and be absorbed easily (29), which makes these peptides useful as an ingredient in functional foods.

In all of the peptide sequences, the majority of amino acid residues are hydrophobic. He et al. (32) suggested that a high quantity of hydrophobic amino acids (branched side chain or aromatic), such as Pro, Glu, Val, Phe and Tyr, particularly at the C-terminal end of the peptide, enhances the ACE inhibitory capacity of the hydrolysate (32). Therefore, the high ACE inhibitory activity of separated hydrolysates might lie in the high content of these amino acids in the peptide sequence. However, as Li et al. (37) suggested, the presence of hydrophilic amino acids within the peptide sequence at certain intervals between hydrophobic amino acids plays an important role in ACE inhibitory activity too.

It has been reported that the presence of repeating dior tripeptides within the peptide sequence enhances the bioactivity of the peptide as compared to the same individual amino acids (13). In our study, the presence of repeating amino acids, such as Ala-Ala, Pro-Pro and Leu-Leu, was observed within the identified peptide sequences.

In addition, the identified peptides contain shorter fragments (i.e. certain dipeptides, tripeptides, etc.) such as Leu-Gly, Gly-Pro, Gly-Pro-Ala, Leu-Gly-Pro-Val and many others within their sequence, which have been confirmed as ACE inhibitors and/or antioxidants $(29,38)$. In order to

Table 2. Identification of peptide sequences with the highest bioactivity from three different hydrolysates

\begin{tabular}{|c|c|c|c|c|c|c|c|c|}
\hline \multicolumn{3}{|c|}{ Trypsin $1 \mathrm{~h}$} & \multicolumn{3}{|c|}{ Trypsin $3 \mathrm{~h}$} & \multicolumn{3}{|c|}{ Protamex $9 \mathrm{~h}$} \\
\hline Peptide sequence & $M_{\mathrm{r}} / \mathrm{Da}$ & Score $^{*}$ & Peptide sequence & $M_{\mathrm{r}} / \mathrm{Da}$ & Score & Peptide sequence & $M_{\mathrm{r}} / \mathrm{Da}$ & Score \\
\hline GCGLGDPPGHGK & 1093.498 & 0.82 & ALGPSGAAGPAGPDGR & 1349.669 & 0.67 & WGPGPPGDLGAA & 1093.519 & 0.84 \\
\hline AAGPAGPDGR & 867.420 & 0.74 & LGPVGDCKGPPK & 1166.612 & 0.64 & DPGAGPPGDLGAA & 1093.504 & 0.76 \\
\hline LGPVMMLGHGR & 1166.605 & 0.70 & GSLGPVGDPGGSVGR & 1310.658 & 0.64 & VPVPGPL & 677.411 & 0.70 \\
\hline ALGPSGAAGPAGDPGR & 1349.669 & 0.70 & GSLGPVGDPGQVGR & 1294.663 & 0.58 & LEGPPGPY & 828.402 & 0.53 \\
\hline LGPVGDCKGPPK & 1166.612 & 0.64 & SLGPVGDPGQVGR & 1237.641 & 0.52 & & & \\
\hline GPQGPAGELGEQGR & 1351.648 & 0.58 & LGPVGDPGQVGR & 1150.609 & 0.51 & & & \\
\hline GSLGPVGDPGQVGR & 1294.663 & 0.54 & ALGPSGAAQPGPDGR & 1349.669 & 0.50 & & & \\
\hline MGAGLLGHK & 882.475 & 0.51 & & & & & & \\
\hline
\end{tabular}

*The score was obtained from PeptideRanker (35) 
Table 3. Bioactive subsequences within the identified potentially bioactive peptides from three different hydrolysates

\begin{tabular}{|c|c|c|}
\hline $\begin{array}{l}\text { Bioactive } \\
\text { fragment }\end{array}$ & Peptide & Bioactivity \\
\hline GP & $\begin{array}{l}\text { AAGPAGPDGR, LGPVMMLGHGR, ALGPSGAAGPAGDPGR LGPVGDCKGPPK, } \\
\text { GPQGPAGELG, GSLGPVGDPGQVGR ALGPSGAAGPAGPDGR, LGPVGDCKGPPK, } \\
\text { WGPGPPGDLGAA, GSLGPVGDPGGSVGR, VPVPGPL GSLGPVGDPGQVGR, LEGPPGPY, } \\
\text { DPGAGPPGDLGAA, SLGPVGDPGQVGR, LGPVGDPG, ALGPSGAAQPGPDGR }\end{array}$ & $\begin{array}{l}\text { ACE inhibitory }{ }^{1,2} \\
\text { Antioxidant activity }^{1}\end{array}$ \\
\hline GL & GCGLGDPPGHGK, MGAGLLGHK & $\begin{array}{l}\text { ACE inhibitory }{ }^{1,2} \\
\text { Antioxidant activity }^{1}\end{array}$ \\
\hline GK & GCGLGDPPGHGK & $\begin{array}{l}\text { ACE inhibitory } y^{1,2} \\
\text { Antioxidant activity }\end{array}$ \\
\hline AA & $\begin{array}{l}\text { ALGPSGAAGPAGDPGR, AAGPAGPDGR, ALGPSGAAGPAGPDGR, DPGAGPPGDLGAA, } \\
\text { ALGPSGAAQPGPDGR, WGPGPPGDLGAA }\end{array}$ & $\begin{array}{l}\text { ACE inhibitory }{ }^{1,2} \\
\text { Antioxidant activity }^{1,2}\end{array}$ \\
\hline GH & GCGLGDPPGHGK, LGPVMMLGHGR, MGAGLLGHK & $\begin{array}{l}\text { ACE inhibitory }{ }^{1,2} \\
\text { Antioxidant activity }^{1}\end{array}$ \\
\hline GR & $\begin{array}{l}\text { GPQGPAGELGEQGR, GSLGPVGDPGQVGR, AAGPAGPDGR LGPVMMLGHGR, } \\
\text { ALGPSGAAGPAGDPGR GSLGPVGDPGGSVGR, LGPVGDPGQVGR, GSLGPVGDPGQVGR, } \\
\text { SLGPVGDPGQVGR, ALGPSGAAQPGPDGR, ALGPSGAAGPAGPDGR }\end{array}$ & ACE inhibitory ${ }^{1,2}$ \\
\hline HG & GCGLGDPPGHGK, LGPVMMLGHGR & $\begin{array}{l}\text { ACE inhibitory }{ }^{1,2} \\
\text { Antioxidant activity }^{1}\end{array}$ \\
\hline GD & $\begin{array}{l}\text { GCGLGDPPGHGK, ALGPSGAAGPAGDPGR, QVGRLGPVGDCKGPPK, GSLGPVGDPGQVGR, } \\
\text { WGPGPPGDLGAA } \\
\text { LGPVGDCKGPPK, DPGAGPPGDLGAA, SLGPVGDPGQVGR GSLGPVGDPGGSVGR, } \\
\text { GSLGPVGDPGQVGR, LGPVGDPG }\end{array}$ & $\begin{array}{l}\text { ACE inhibitory }{ }^{1} \\
\text { Antioxidant activity }^{1}\end{array}$ \\
\hline PV & $\begin{array}{l}\text { GSLGPVGDPGQVGR, LGPVGDCKGPPK, LGPVMMLGHGR, LGPVGDCKGPPK, } \\
\text { GSLGPVGDPGGSVGR, VPVPGPLSLGPVGDPGQVGR, LGPVGDPGQVGR }\end{array}$ & $\begin{array}{l}\text { ACE inhibitory }{ }^{1,2} \\
\text { Antioxidant activity }^{1}\end{array}$ \\
\hline LG & $\begin{array}{l}\text { GCGLGDPPGHGK, LGPVMMLGHGR, ALGPSGAAGPAGDPGR, SLGPVGDPGQVGR, } \\
\text { LGPVGDCKGPPK, GPQGPAGELG, GSLGPVGDPGQVGR, LGPVGDPG MGAGLLGHK, } \\
\text { ALGPSGAAGPAGPDGR, LGPVGDCKGPPK DPGAGPPGDLGAA, WGPGPPGDLGAA } \\
\text { ALGPSGAAQPGPDGR, GSLGPVGDPGGSVGR, GSLGPVGDPGQVGR, }\end{array}$ & $\begin{array}{l}\text { ACE inhibitory }{ }^{1,2} \\
\text { Antioxidant activity }^{1}\end{array}$ \\
\hline PG & $\begin{array}{l}\text { ALGPSGAAGPAGDPGR, GSLGPVGDPGGSVGR, LEGPPGPY GSLGPVGDPGQVGR, } \\
\text { SLGPVGDPGQVGR, LGPVGDPG GSLGPVGDPGQVGR, ALGPSGAAQPGPDGR, } \\
\text { VPVPGPL GCGLGDPPGHGK, WGPGPPGDLGAA, DPGAGPPGDLGAA }\end{array}$ & $\begin{array}{l}\text { ACE inhibitory }{ }^{1,2} \\
\text { Antioxidant activity }^{1}\end{array}$ \\
\hline $\mathrm{PP}$ & LGPVGDCKGPPK, WGPGPPGDLGAA, DPGAGPPGDLGAA LEGPPGPY & $\begin{array}{l}\text { ACE inhibitory }{ }^{1,2} \\
\text { Antioxidant activity }^{1,2}\end{array}$ \\
\hline GPA & GPQGPAGELGEQGR, ALGPSGAAGPAGDPGR AAGPAGPDGR, ALGPSGAAGPAGPDGR & $\begin{array}{l}\text { ACE inhibitory } \\
\text { Antioxidant activity }^{1}\end{array}$ \\
\hline LGPV & $\begin{array}{l}\text { GSLGPVGDPGQVGR, LGPVGDCKGPPK, LGPVMMLGHGR LGPVGDCKGPPK, } \\
\text { GSLGPVGDPGGSVGR LGPVGDPGQVGR, GSLGPVGDPGQVGR SLGPVGDPGQVGR }\end{array}$ & ACE inhibitory ${ }^{1}$ \\
\hline GDP & $\begin{array}{l}\text { GSLGPVGDPGQVGR, ALGPSGAAGPAGDPGR GCGLGDPPGHGK, GSLGPVGDPGGSVGR } \\
\text { GSLGPVGDPGQVGR, SLGPVGDPGQVGR LGPVGDPGQVGR }\end{array}$ & Antioxidant activity ${ }^{1}$ \\
\hline
\end{tabular}

${ }^{1}$ BIOPEP database (39)

${ }^{2}$ EROP-Moscow database (40)

find these short peptides, the identified bioactive peptides were investigated using two bioactive peptide databases, BIOPEP (39) and EROP-Moscow (40). Some of the identified subsequences are summarized in Table 3. However, it should be considered that this study provides only some of the potential bioactive subsequences and there might be more unknown components that play an important role in exhibiting ACE inhibitory and antioxidant activities of the isolated peptides.

Many factors concurrently affect the bioactivity of peptides, and it is not easy to identify the best peptide from one type of protein to compare with similar peptides from other proteins. Although the amino acid sequence of a bioactive peptide is an important parameter in conferring high bioactivity (ACE inhibitory and antioxidant activities), amino acid composition and the sequence of the rest of the peptides, which depend on the parent protein, can be important parameters as well, and there is an assumption that the presence of some other fractions can have a synergistic effect on the bioactivity of the detected bioactive ones (4). In addition, other factors such as concentration of the hydrolysate, $\mathrm{pH}$, and temperature can be the reasons for differences in reports about same proteins.

\section{Conclusion}

The ACE inhibitory activity and antioxidant activity of jellyfish collagen hydrolysates obtained using three different enzymes were studied. The isolated peptides showed considerable antioxidant and ACE inhibitory activities. Therefore, this underutilized resource may prove useful as a food additive, ingredient for functional foods, and nu- 
traceutical and pharmaceutical agent. The results of this study also suggest that exposure to different proteases and different degrees of hydrolysis affects the bioactivity potency of the hydrolysate from the same parent protein.

\section{Acknowledgements}

This project was financially supported by a Universiti Sains Malaysia fellowship and two research grants (ERGS grant: 203/CAATS/6730103 and short term grant: 304/ PCAATS/6312045).

\section{References}

1. C. Zhang, W. Cao, P. Hong, H. Ji, X. Qin, J. He, Angiotensin I-converting enzyme inhibitory activity of Acetes chinensis peptic hydrolysate and its antihypertensive effect in spontaneously hypertensive rats, Int. J. Food Sci. Tech. 44 (2009) 2042-2048. http://dx.doi.org/10.1111/j.1365-2621.2009.02028.x

2. B. Sarmadi, A. Ismail, M. Hamid, Antioxidant and angiotensin converting enzyme (ACE) inhibitory activities of cocoa (Theobroma cacao L.) autolysates, Food Res. Int. 44 (2011) 290-296. http://dx.doi.org/10.1016/j.foodres.2010.10.017

3. H.D. Yoon, Y.K. Kim, C.W. Lim, S.M. Yeun, M.H. Lee, H.S. Moon et al., ACE-inhibitory properties of proteolytic hydrolysates from giant jellyfish Nemopilema nomurai, Fish. Aquat. Sci. 14 (2011) 174-178.

4. S. Raghavan, H.G. Kristinsson, ACE-inhibitory activity of tilapia protein hydrolysates, Food Chem. 117 (2009) 582-588. http://dx.doi.org/10.1016/j.foodchem.2009.04.058

5. Y.L. Zhuang, X. Zhao, B.F. Li, Optimization of antioxidant activity by response surface methodology in hydrolysates of jellyfish (Rhopilema esculentum) umbrella collagen, J. Zhejiang Univ. Sci. B, 10 (2009) 572-579.

http://dx.doi.org/10.1631/jzus.B0920081

6. B. Giménez, A. Alemán, P. Montero, M.C. Gómez-Guillén, Antioxidant and functional properties of gelatin hydrolysates obtained from skin of sole and squid, Food Chem. 114 (2009) 976-983.

http://dx.doi.org/10.1016/j.foodchem.2008.10.050

7. I.W.Y. Cheung, E.C.Y. Li-Chan, Angiotensin-I-converting enzyme inhibitory activity and bitterness of enzymatically-produced hydrolysates of shrimp (Pandalopsis dispar) processing byproducts investigated by Taguchi design, Food Chem. 122 (2010) 1003-1012.

http://dx.doi.org/10.1016/j.foodchem.2010.03.057

8. J. Wu, X. Ding, Hypotensive and physiological effect of angiotensin converting enzyme inhibitory peptides derived from soy protein on spontaneously hypertensive rats, J. Agric. Food Chem. 49 (2001) 501-506. http://dx.doi.org/10.1021/jf000695n

9. R.J. FitzGerald, H. Meisel, Lactokinins: Whey protein-derived ACE inhibitory peptides, Food/Nahrung, 43 (1999) 165-167.

10. M. Miguel, M.A. Manso, R. López-Fandi-o, M.J. Alonso, M. Salaices, Vascular effects and antihypertensive properties of к-casein macropeptide, Int. Dairy J. 17 (2007) 1473-1477. http://dx.doi.org/10.1016/j.idairyj.2007.04.009

11. H.T.M. Nguyen, K.S.B. Sylla, Z. Randriamahatody, C. Donnay-Moreno, J. Moreau, L.T. Tran, J.P. Bergé, Enzymatic hydrolysis of yellowfin tuna (Thunnus albacares) by-products using Protamex protease, Food Technol. Biotechnol. 49 (2011) 48-55.

12. F.X. Cui, C.H. Xue, Z.J. Li, Y.Q. Zhang, P. Dong, X.Y. Fu et al., Characterization and subunit composition of collagen from the body wall of sea cucumber Stichopus japonicus, Food Chem. 100 (2007) 1120-1125.

http://dx.doi.org/10.1016/j.foodchem.2005.11.019

13. H.L. Siow, C.Y. Gan, Extraction of antioxidative and antihypertensive bioactive peptides from Parkia speciosa seeds, Food Chem. 141 (2013) 3435-3442.

http://dx.doi.org/10.1016/j.foodchem.2013.06.030

14. E. Maghsoudlou, Molecular taxonomy, population genetics and reproductive studies of the jellyfish (Scyphozoa) in Malaysian waters, $\mathrm{PhD}$ Thesis, Universiti Sains Malaysia, Penang, Malaysia (2012).

15. T. Nagai, T. Ogawa, T. Nakamura, T. Ito, H. Nakagawa, K. Fujiki et al., Collagen of edible jellyfish exumbrella, J. Sci. Food Agric. 79 (1999) 855-858.

http://dx.doi.org/10.1002/(SICI)1097-0010(19990501)79:6<855: :AID-JSFA299>3.0.CO;2-N

16. Z. Barzideh, A.A. Latiff, C.Y. Gan, S. Benjakul, A. Abd Karim, Isolation and characterisation of collagen from the ribbon jellyfish (Chrysaora sp.), Int. J. Food Sci. Tech. 49 (2013) 1490-1499. http://dx.doi.org/10.1111/ijfs.12464

17. J.F. Ding, Y.Y. Li, J.J. Xu, X.R. Su, X. Gao, F.P. Yue, Study on effect of jellyfish collagen hydrolysate on anti-fatigue and anti-oxidation, Food Hydrocolloid. 25 (2011) 1350-1353. http://dx.doi.org/10.1016/j.foodhyd.2010.12.013

18. Y. Zhuang, L. Sun, B. Li, Production of the angiotensin-I-converting enzyme (ACE)-inhibitory peptide from hydrolysates of jellyfish (Rhopilema esculentum) collagen, Food Bioprocess Technol. 5 (2012) 1622-1629. http://dx.doi.org/10.1007/s11947-010-0439-9

19. N.T. Hoyle, J. Merritt, Quality of fish protein hydrolysates from herring (Clupea harengus), J. Food Sci. 59 (1994) 76-79. http://dx.doi.org/10.1111/j.1365-2621.1994.tb06901.x

20. N. J. Thiex, H. Manson, S. Anderson, J. A. Persson, Determination of crude protein in animal feed, forage, grain, and oilseeds by using block digestion with a copper catalyst and steam distillation into boric acid: Collaborative study, J. AOAC Int. 85 (2002) 309-317.

21. C.G. Zarkadas, C. Gagnon, V. Poysa, S. Khanizadeh, E.R. Cober, V. Chang, S. Gleddie, Protein quality and identification of the storage protein subunits of tofu and null soybean genotypes, using amino acid analysis, one-and two-dimensional gel electrophoresis, and tandem mass spectrometry, Food Res. Int. 40 (2007) 111-128. http://dx.doi.org/10.1016/j.foodres.2006.08.005

22. S. Moore, On the determination of cystine as cysteic acid, J. Biol. Chem. 238 (1963) 235-237.

23. I.F.F. Benzie, J.J. Strain, The ferric reducing ability of plasma (FRAP) as a measure of antioxidant power: The FRAP assay, Anal. Biochem. 239 (1996) 70-76. http://dx.doi.org/10.1006/abio.1996.0292

24. J.R. Lee, D.Y. Kwon, H.K. Shin, C.B. Yang, Purification and identification of angiotensin-I converting enzyme inhibitory peptide from kidney bean protein hydrolysate, Food Sci. Biotechnol. 8 (1999) 172-178.

25. D.W. Cushman, H.S. Cheung, Spectrophotometric assay and properties of the angiotensin-converting enzyme of rabbit lung, Biochem. Pharmacol. 20 (1971) 1637-1648. http://dx.doi.org/10.1016/0006-2952(71)90292-9

26. A. Alemán, B. Giménez, P. Montero, M.C. Gómez-Guillén, Antioxidant activity of several marine skin gelatins, LWTFood Sci. Technol. 44 (2011) 407-413. http://dx.doi.org/10.1016/j.lwt.2010.09.003

27. W.A.A.Q.I. Wan Mohtar, A.A. Hamid, S. Abd-Aziz, S.K.S. Muhamad, N. Saari, Preparation of bioactive peptides with high angiotensin converting enzyme inhibitory activity from 
winged bean [Psophocarpus tetragonolobus (L.) DC.] seed, J. Food Sci. Technol. (2013) 1-11. http://dx.doi.org/10.1007/s13197-012-0919-1

28. C.C. Udenigwe, R.E. Aluko, Chemometric analysis of the amino acid requirements of antioxidant food protein hydrolysates, Int. J. Mol. Sci. 12 (2011) 3148-3161. http://dx.doi.org/10.3390/ijms12053148

29. H.G. Byun, J.K. Lee, H.G. Park, J.K. Jeon, S.K. Kim, Antioxidant peptides isolated from the marine rotifer, Brachionus rotundiformis, Process Biochem. 44 (2009) 842-846. http://dx.doi.org/10.1016/j.procbio.2009.04.003

30. M. Alothman, R. Bhat, A.A. Karim, Antioxidant capacity and phenolic content of selected tropical fruits from Malaysia, extracted with different solvents, Food Chem. 115 (2009) 785-788. http://dx.doi.org/10.1016/j.foodchem.2008.12.005

31. Q. Liu, B. Kong, Y.L. Xiong, X. Xia, Antioxidant activity and functional properties of porcine plasma protein hydrolysate as influenced by the degree of hydrolysis, Food Chem. 118 (2010) 403-410. http://dx.doi.org/10.1016/j.foodchem.2009.05.013

32. H.L. He, X.L. Chen, H. Wu, C.Y. Sun, Y.Z. Zhang, B.C. Zhou, High throughput and rapid screening of marine protein hydrolysates enriched in peptides with angiotensin-I-converting enzyme inhibitory activity by capillary electrophoresis, Bioresour. Technol. 98 (2007) 3499-3505. http://dx.doi.org/10.1016/j.biortech.2006.11.036

33. H.J. Suh, J.H. Whang, Y.S. Kim, S.H. Bae, D.O. Noh, Preparation of angiotensin I converting enzyme inhibitor from corn gluten, Process Biochem. 38 (2003) 1239-1244. http://dx.doi.org/10.1016/S0032-9592(02)00316-3
34. W.D. Chiang, M.J. Tsou, Z.Y. Tsai, T.C. Tsai, Angiotensin Iconverting enzyme inhibitor derived from soy protein hydrolysate and produced by using membrane reactor, Food Chem. 98 (2006) 725-732. http://dx.doi.org/10.1016/j.foodchem.2005.06.038

35. C. Mooney, N.J. Haslam, G. Pollastri, D.C. Shields, Towards the improved discovery and design of functional peptides: Common features of diverse classes permit generalized prediction of bioactivity, PLoS ONE, 7 (2012) e45012. http://dx.doi.org/10.1371/journal.pone.0045012

36. H. Korhonen, A. Pihlanto, Bioactive Peptides: production and functionality, Int. Dairy J. 16 (2006) 945-960. http://dx.doi.org/10.1016/j.idairyj.2005.10.012

37. G.H. Li, G.W. Le, Y.H. Shi, S. Shrestha, Angiotensin I-converting enzyme inhibitory peptides derived from food proteins and their physiological and pharmacological effects, Nutr. Res. 24 (2004) 469-486. http://dx.doi.org/10.1016/S0271-5317(04)00058-2

38. S. K. Kim, E. Mendis, Bioactive compounds from marine processing byproducts - A review, Food Res Int. 39 (2006) 383-393. http://dx.doi.org/10.1016/j.foodres.2005.10.010

39. BIOPEP database, Chair of Food Biochemistry, University of Warmia and Mazury in Olsztyn, Olsztyn, Poland (http:// www.uwm.edu.pl/biochemia/index.php/en/biopep, access date: 14.09.2014).

40. EROP-Moscow database, Computer Biochemistry Group, A.N. Bach Institute of Biochemistry, Russian Academy of Sciences, Moscow, Russian Federation (http://erop.inbi.ras. $\mathrm{ru} / \mathrm{index} \cdot \mathrm{html}$, access date: 14.09.2014). 